Equalita, Vol. 3 Issue 1, Juni 2021

Avaliable online at http://syekhnurjati.ac.id/jurnal/index.php/equalita/article/view/8631

Diterbitkan oleh Pusat Studi Gender dan Anak LP2M IAIN Syekh Nurjati Cirebon, Indonesia

\title{
LAKI-LAKI ATAU PEREMPUAN, ADALAH PEMIMPIM KELUARGA?
}

\author{
Nama* \\ Wakhid Hasim \\ IAIN Syekh Nurjati Cirebon
}

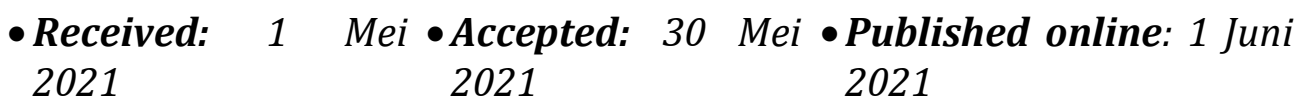

\begin{abstract}
:
Artikel ini berupaya untuk memahami kepemimpinan keluarga dalam masyarakat muslim dalam konteks kehidupan modern. Fokus kajiannya adalah konsep tentang kepemimpinan dalam keluarga, kepemimpinan laki-laki, kepemimpinan perempuan, dan peluang laki-laki untuk bekerjasama dalam memimpin keluarga bersama perempuan. Paparan dapat memberi beberapa pelajaran antara lain pertama, bahwa perubahan sosial mempengaruhi terhadap perubahan keluarga, termasuk kepemimpinan laki-laki dan relasi gender. Kedua, secara tekstual keagamaan, makna kepemimpinan dapat diperluas tidak saja oleh laki-laki, namun juga oleh perempuan. Kepemimpinan dapat dimaknai sebagai kewenangan mengambil keputusan, dan kewenangan melaksanakan hasil keputusan musyawarah keluarga. Ketiga, laki-laki dalam konteks masyarakat patriarki memiliki modalitas kuat untuk berkerjasama dengan perempuan dalam memimpin keluarga, baik dari aspek dominasi, signifikasi maupun legitimasi.
\end{abstract}

Kata kunci: Laki-laki, Perempuan, Keluarga, Semantic, tafsir.

\section{Abstract}

This article seeks to understand family leadership in Muslim society in the context of modern life. The focus of the study is the concept of leadership in the family, male leadership, female leadership, and opportunities for men to work together in leading the family with women. The presentation can provide several lessons, among others, first, that social changes affect family changes, including male leadership and gender relations. Second, religiously, the meaning of leadership can be expanded not only by men, but also by women. Leadership can be interpreted as the authority to make decisions, and the authority to carry out the results of family deliberation decisions. Third, men in the context of a patriarchal society have a strong modality to cooperate with women in leading the family, both in terms of dominance, significance and legitimacy.

Keywords: Men, Women, Family, Semantic, Interpretation. 


\section{A. PENDAHULUAN}

Bagi kaum muslim yang taat beragama, berkeluarga di lingkungan masyarakat modern memiliki tuntutan yang tidak mudah. Peraturan hukum Islam menuntut keluarga untuk menaati batasan-batasannya di satu sisi, di sisi lain batasan-batasan tersebut tidak selalu sesuai dengan situasi modern. Misalnya aturan kepemimpinan, siapa yang harus memimpin keluarga. Pandangan umum mengatakan bahwa laki-laki memimpin keluarga karena memiliki kelebihan dari perempuan dan karena ia memberi nafkah kepada perempuan. Masalahnya, bagaimana dengan perempuan yang justru memiliki kelebihan dari laki-laki? Bagaimana dengan perempuan yang menjadi tulang punggung nafkah keluarga?

Sebagian kelompok masyarakat tidak memedulikan masalah ini dengan alasan perkara agama seyogyanya dilakukan dengan semangat menaati syari'at Allah dan RasulNya. Namun kelompok lain mempertanyakan sikap demikian tersebut tidak sesuai dengan prinsip pelaksanaan syariat, misalnya prinsip memudahkan dan tidak menyulitkan (yassir wala tu'assir), prinsip penyesuaian konteks sosial (taghayyurul ahkam bi taghoyyuril ahwal, wal amkan wal azminah), dan prinsip memegang tujuan syariat (maqashid asy-syari'ah).

Artikel ini berupaya untuk memahami kepemimpinan keluarga dalam masyarakat muslim dalam konteks kehidupan modern. Fokus kajiannya adalah konsep tentang kepemimpinan dalam keluarga, kepemimpinan laki-laki, kepemimpinan perempuan, dan peluang laki-laki untuk bekerjasama dalam memimpin keluarga bersama perempuan.

Metodologi pembahasan tulisan ini menggunakan analisis semantik atas Qur'an Surat Annisa: 34 untuk memahami konsep kepemimpinan laki-laki dan perempuan dalam keluarga, dan menggunakan pendekatan sosiologis untuk penerapan kerjasama laki-laki dan perempuan dalam memimpin keluarga. Analisis semantik dilakukan dengan memanfaatkan analisis makna ungkapan sintakmatik (manthuq) dan paradigmatik melalui pemahaman konteks secara sistemik (mafhum). Analisis sintakmatik (manthuq) memakai seperangkat alat analisis antara lain pemaknaan denotatif tersurat ('ibaroh), maupun tersirat (isyaroh). Sedangkan analisis paradigmatic (mafhum) menggunakan alat konsekuensi konteks kalimat (mafhum muwafaqoh) maupun konsekuensi konteks makna di luar kalimat yang sifatnya negasi (mafhum mukholafah). Metode-metode ini dilengkapi dengan prinsip-prinsip analisis menggunakan kaidah tafsir, usul figh dan teori sosial yang relevan.

\section{B. METODOLOGI PENELITIAN}

Paper ini menggunakan pendekatan semantic dan sosiologis atas tafsir surat annisa:34.

\section{RESULT AND DISCUSSION}

\section{A. Laki-laki sebagai Pemimpin Keluarga dan Masalah Redaksi Teks Q.S. Annisa: 34}

Ayat 34 Surat Annisa berbunyi sebagai berikut.

$$
\text { و بما انفقو امن امو الهى النساء بما فضل الله بعضهم على بعض }
$$


Para laki-laki menjadi pemimpin atas para perempuan karena Allah

telah melebihkan sebagian dari laki-laki atas sebagian dari

perempuan dan karena para laki-laki telah memberi nafkah dengan

sebagian dari harta mereka.

Ayat ini menjadi alasan mendasar bagi kepemimpinan laki-laki dalam Islam, baik kepemimpinan dalam keluarga maupun di masyarakat. Ayat ini juga menjadi pokok argumen pada praktik sosial gender yang menyangkut relasi laki-laki dan perempuan, misalnya aturan bagian waris, aturan wali nikah, nilai suara dalam persaksian, dan praktik keagamaan lainnya.

Terkait masalah yang diajukan pada sub bab pengantar di atas, yaitu bagaimana jika perempuan memiliki kelebihan dari perempuan dan memberi nafkah keluarga, posisi mendasar sebagai pokok argument relasi gender ini penting untuk diuraikan. Perempuan dalam posisi seperti itu secara logis dapat menjadi pemimpin bagi keluarga, namun demikian perlu kehati-hatian supaya tidak hanya berargumen secara rasional belaka, namun juga menggunakan aturan tafsir terhadap nash Qur'an.

Berikut kita akan telusuri alasannya melalui analisis atas pilihan kata dalam ayat (mufrodat), lalu bentuk kalimat, makna indikatif (isyarat) dari lafadz, dan makna konsekuensial (mafhum mukholafah).

1. Kepemimpinan Laki-laki tidak otomatis, namun memiliki syarat yang harus dipenuhi

Laki-laki menjadi pemimpin perempuan memiliki dua alasan yaitu "memiliki kelebihan yang diberikan oleh Allah" dan "telah menafkahi dengan menggunakan sebagian hartanya". Pada struktur sintaktik ayat ini terdapat makna isyarat bahwa laki-laki yang tidak memenuhi syarat tersebut tidak dapat menjadi pemimpin keluarga. Sebagai konsekuensi dari makna isyarat ini, perempuan yang memenuhi kreteria kepemimpinan keluarga ini dapat menjadi pemimpin keluarga.

Argumen yang dapat diajukan untuk kesimpulan tersebut dengan menganalisis konsep kelebihan atau " $f a d h l$ ", fungsi kata depan "bi" dalam kata "bi ma fadhalallohu", konsep kepemimpinan dalam kata "qowam", dan makna isyarat dari kata sebagian atau "ba'dh" dalam kata "ba'dhahum 'ala ba'dh".

a. Makna kata fadl (فضل), sifat lebih dari laki-laki

Syekh Ahmad Ash-showy Al-Maliki dalam tafsir Ash-Showy (Ash-Showy, 217-218) memberi penjelasan bahwa kelebihan laki-laki atas perempuan ada dua macam, kelebihan yang diberikan (wahbiyah) dan kelebihan yang diupayakan (kasbiyah). Dalam penjelasannya, kelebihan yang diberikan oleh Allah terkait dengan peran dan tugas keagamaan seperti menjadi imam, mendapat kewajiban sholat jum'at, menjadi jamaah utama, dan eksistensi nabi yang berjenis kelamin laki-laki. Berbeda dengan itu, kelebihan yang diupayakan antara lain kualitas akal, suara persaksian yang bernilai dua suara perempuan, kemampuan menjadi pemimpin negara/khalifah, memiliki hak poligami, dan memiliki hak untuk talak dan rujuk (Ash-Showi, 218).

Al-Qurtuby dalam Kitabnya Al-Jami' li Ahkami Al-Qurani, Juz ke-5, menyatakan bahwa kelebihan laki-laki dibanding perempuan dilihat dari keunggulannya dalam akal dan pemikiran, hakikat jiwa dan materi badannya yang panas dan basah dibanding perempuan yang dingin dan kering (Al-Qurtuby, 169). Dengan kelebihan-kelebihan ini, laki-laki memimpin dengan menanggung nafkah 
dan membela perempuan, laki-laki menjadi hakim, memerintah, dan maju di medan perang, hal yang tidak dapat dilakukan oleh perempuan (Al-Qurtuby, 168).

Dengan menafikan peran dan tugas keagamaan, kualitas-kualitas lebih dari laki-laki yang diungkapkan Ash-Showy dan Al-Qurthuby dapat mengacu kepada kualitas-kualitas yang dapat diupayakan. Kualitas-kualitas ini tidak langsung diwarisi, namun perlu dilatih dan dipelajari. Baik laki-laki maupun perempuan dengan demikian dapat mempelajari dan mendapatkannya.

Pertanyaannya, apakah tugas dan peran keagamaan yang diberikan oleh Allah kepada laki-laki tergantung dari kualitas laki-laki yang diupayakan tersebut, atau melekat pada jenis kelaminnya? Dalam hal ini kita perlu melihat konteks kalimat lebih lanjut.

b. Makna kata sambung bi-sababiyah (ب) dan ma-mashdariyah/maushuliyah ) ( L

Kata sambung "bi" (dengan) dalam kalimat ayat "bi ma fadhalallohu ba'dhohum 'ala ba'dh" dan "wa bima anfaqu min amwalihim" menurut Ash-Showy bermakna sebab (bi sababiyah). Artinya, laki-laki menjadi pemimpin itu dengan adanya "sebab", yaitu memiliki kelebihan dan menafkahi perempuan. Sedangkan kata sambung "ma" berfungsi mashdariyah atau (adverb). Artinya, pengangkatan laki-laki menadi pemimpin itu "dengan cara" memberikan kelebihan kepada laki-laki atas perempuan. Ada pula yang memaknai artikel "ma" berfungsi kata sambung "yang" (maushuliyah), maksudnya karena kelebihan yang diberikan oleh Allah.

Apa gunanya memperhatikan fungsi artikel bi dengan fungsi penyebab, dan ma dengan fungsi mashdariyah dan maushuliyah di atas? Bagi Imam Al-Qurthuby dua alasan ini sangat serius terkait dengan eksistensi akad perkawinan. Jika dua alasan ini tidak terpenuhi, maka akad nikah ini rusak (fasakh). Hal ini dikuatkan oleh pandangan madhab Maliki dan madzhab Syafi'y, walaupun ditolak oleh madzhab Hanafy. Bagi madzhab Hanafy, sekalipun alasan ini tidak terpenuhi, perkawinan tidak rusak dengan sendirinya karena semangat agama tidak boleh mempersulit, "wa in kana zu 'usrotin fanazirotun ila maisartin" (Alqurtuby: 169).

Pandangan Al-Qurtuby cukup kontroversial jika kita pandang dari kaca mata modern, dengan sistem peradilan yang bersifat formal di Lembaga Pengadilan Negeri/Agama. Di Indonesia, seseorang yang menalak istrinya, selagi belum diketahui secara formal di Pengadilan Agama, maka status perkawinannya masih dianggap belum rusak, sampai Pengadilan Agama memutuskannya. Namun pandangan ini menarik dari aspek pemaknaan terhadap konsep kepemimpinan lakilaki. Kita dapat memaknai bahwa kepemimpinan ini membawa konsekuensi, namun tidak perlu sampai pada rusaknya perkawinan. Lalu bagaimana?

Laki-laki yang tidak mampu memenuhi kualitas unggul dan fungsi menafkahi perempuan dapat mempertimbangkan untuk mengatur ulang fungsi-fungsi bersama dalam menjalankan keluarga. Keluarga adalah kontrak perikatan/aqad antara dua subyek mandiri, laki-laki dan perempuan, menjadi suami dan istri. Subyek hukum dapat bermusyawarah untuk melakukan kerjasama demi kelangsungan keluarga. Siapa, melakukan apa, dengan cara bagaimana, merupakan hakikat kontrak yang sepadan antar laki-laki dan perempuan secara fungsional, dengan mengabaikan kedudukan formal kepemimpinan. Lalu bagaimana caranya?

Hal ini sangat terkait dengan makna konsep kepemimpinan dalam kata "qowam". Apakah makna ini terkait dengan otoritas/kewenangan memutuskan 
masalah keluarga (leadership), ataukah terkait dengan kewenangan melaksanakan kesepakatan (manajerial), atau kombinsi keduanya? Penjelasannya ada di bawah ini.

c. Makna kata "qowwam( قوام), memimpin

Makna denotatif dalam kamus Bahasa Arab Al-Munawwir terkait kata qoma, meliputi tiga kombinasi. Pertama, "qoma 'ala", berarti membantu, mengamati, menjaga, menetapi. Kedua, "qoma bi" berarti menguasai, menunaikan, melakukan, dan ketiga "qoma fi" berarti memulai mengerjakan. (Al-Munawwir, 1984: 1260/1). Ayat ini menggunakan kata qoma 'ala, lebih mendekati ke arah fungsi manajerial. Namun kita perlu telusuri pandangan para ahli tafsir di bawah ini.

Imam Al-Jalalain dalam Kitab Tafsir Jalalain menafsirkan qowwam bermakna mushollithun, artinya menguasai, dengan mengajarkan sikap adab (yuaddibunahunna) dan bertanggungjawab atas kehidupan perempuan (wa ya'khudzuna 'ala aidiyahunna). Imam Ash-Showi memperjelas maksud kata mushollithun dengan kata memiliki otoritas seperti shulthon, seperti kepala negara kepada rakyatnya. Kepala negara berkuasa dan bertanggungjawab atas kekuasannya kepada rakyatnya (Ash-Showi, 217-218).

Al-Qurtuby menjelaskan bahwa qowwam merupakan gaya superlatif (mubalaghoh) mengikuti pola $f a^{\prime} a l$, berarti menanggung dengan sangat dan menjaganya dengan daya upaya. Dalam konteks ayat ini, laki-laki memiliki kewajiban kepada perempuan dengan cara mendidiknya, menguatkan karakternya, menjaganya di rumah, menncegahknya dari keburukan. Perempuan sebagai gantinya berkewajiban untuk menaati, menjalankn perintahnya yang tidak menyalahi syariat. (Al-Qurtuby: 169).

Penjelasan di atas tampak masih mencampur aduk fungsi kepemimpinan sebagai pengambil keputusan dan sebagai manajer pelaksana keputusan. Al-Jalalain dan Ash-Showi pemaknaan pemimpin sebagai pengambil keputusan dan pelaksana keputusan sekaligus. Al-Qurthuby lebih melihat konteks relasional dalam keluarga, dimana jika satu pihak memberikan kewajibannya, maka dia mendapatkan haknya. Jika laki-laki memenuhi kewajiban memimpin dan memberi nafkah, maka istri harus menunaikan kewajiban taat kepada laki-laki dan menjalankan perintahnya.

Pandangan-pandangan di atas memberi pemahaman bahwa subyek perempuan dalam kepemimpinan keluarga bersifat pasif, dan ditentukan oleh lakilaki. Laki-laki mengambil keputusan, dan perempuan menjalankan sebagian keputusan itu. Penjelasan ini dapat ditangkap sebagai pancaran situasi sosiologis ketika tafsir ini ditulis, dimana posisi perempuan memang dalam keadaan pasif dalam keluarga.

Namun hal ini bertentangan dengan konteks kalimat pada ayat selanjutnya, di mana perempuan memiliki posisi sebagai subyek mandiri dalam keluarga. Hal ini ditunjukkan ketika keluarga mengalami perpecahan, ketika ada kekhawatiran terjadi pembangkangan (nusyuz). Laki-laki sebagai pemegang kuasa dibenarkan untuk melakukan langkah-langkah procedural, dari memberi nasehat, memberi sangsi pisah ranjang, dan memukul tanpa melukai. Pada proses selanjutnya, dipaparkan jika ada syiqoq, yaitu perempuan melakukan penolakan atas semua prosedur itu, maka harus ada perdamaian dengan melibatkan wakil-wakil keluarga keduabelah pihak yang dipercaya. ahliha".

"fa in khiftum syiqoqo bainahuma fab'athu hakaman min ahlihi wa hakaman min 
Posisi Syiqoq menunjukkan, bahwa Surat Annisa memberi ruang bagi perempuan menunjukkan diri sebagai subyek yang diakui. Posisi subyek hukum mandiri ini yang belum ditangkap dengan baik dalam penjelasan tafsir di atas, sehingga memandang konsep kepemimpinan berpusat pada laki-laki, sebagai pengambil keputusan maupun manajer pelaksana keputusan.

Posisi perempuan sebagai subyek yang aktif dalam perikatan keluarga dini dikuatkan oleh pilihan kata "al-rijalu" dan "al-nisau" untuk laki-laki dan perempuan, yakni menggunakan artikel "al" yang berfaidah definitif. Penjelasannya di bawah ini.

d. Makna “al" (ال dalam kata "Al-rijalu" ( الرجال) dan “Al-nisau"( النساء) .

Pada kalimat "ar-rijalu qowwamuna 'ala an-nisai", kata yang bermakna laki-laki dan perempuan menggunakan artikel "al" yang berfungsi definitif. Fungsi definitif mengubah makna laki-laki secara umum menjadi laki-laki tertentu, dan perempuan secara umum menjadi perempuan tertentu. Kalimat itu bermakna "laki-laki tertentu memimpin perempuan tertentu". Jika kita ambil makna konsekuensialnya (mafhum mukholafah), maka kita akan mendapat dua alternatif, yaitu "laki-laki tertentu tidak memimpin perempuan tertentu", dan "perempuan tertentu tidak dipimpin oleh lakilaki tertentu".

Sebagian orang mungkin tidak suka dengan pemaknaan ini, dan cenderung memberi penekanan kepada artikel "al" dengan fungsi "meliputi segala jenis" lakilaki dan perempuan (lil istighro'). Hal ini masuk akal karena dalam kaidah Bahasa Arab, salah satu fungsi artikel "al" ketika masuk pada kata benda jenis seperti "alrojalu" dan "al-nisau" dimaksudkan untuk peliputan keseluruhan laki-laki dan perempuan, dan dengan demikian semakna dengan kondisinya ketika masih umum dan belum tertentu (nakiroh).

Namun pendapat ini jikapun benar, gugur maknanya oleh konteks kalimat selanjutnya, yaitu dengan penyebutan kepemimpinan laki-laki itu memiliki dua alasan, sebagian laki-laki memiliki kelebihan dari Allah atas sebagian perempuan, dan laki-laki menafkahi perempuan. Adanya alasan kepemimpinan, ini merupakan bukti bahwa tidak semua laki-laki dapat memenuhi kreteria kepemimpinan sebagaimana dijelaskan di atas.

Hal ini diperkuat dengan penyebutan kata "sebagian laki-laki" dan "sebagian perempuan". Menurut Ash-showi, sebagian perempuan memang memiliki keunggulan disbanding laki-laki, misalnya adalah Khadijah istri Nabi, Fathiman Azzahro putri Nabi, dan Aisyah bint Abi Bakr istri Nabi. (As-showi: 218). Tidak ada yang memungkiri kelebihan mereka baik dalam ketaatan dan keilmuan dari sahabat Nabi lainnya.

Sampai di sini penjelasan dalam bab di atas dapat disimpulkan, pertama, lakilaki dapat menjadi pemimpin bagi perempuan di rumah hanya jika memenuhi dua kreteria yaitu memiliki kelebihan dan menafkahi perempuan dengan sebagian hartanya. Kedua, sebagai konsekuensi secara afirmatif (mafhum muwafaqoh) bermakna hanya sebagian laki-laki saja yang dapat menjadi pemimpin bagi perempuan. Ketiga, secara negasi (mafhum mukholafah) dapat dimaknai bahwa sebagian perempuan tidak dipimpin oleh laki-laki. Kesimpulan ini diperkuat oleh kaidah:

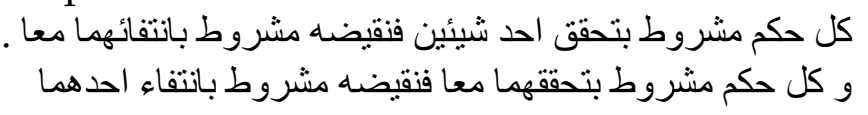


"Setiap hukum yang dipersyaratkan adanya dengan adanya salah satu dua hal, kebalikannya (mafhum mukholafah) dipersyaratkan dengan tiadanya keduanya sekaligus. Dan setiap hukum yang dipersyaratkan adanya dengan adanya dua hal sekaligus, kebalikannya, dipersyaratkan dengan tiadanya salah satunya. (Harun, hal. 707). Keempat, bahwa perempuan dapat menjadi pemimpin dalam keluarga.

\section{B. Keluarga dan Kepemimpinan Perempuan}

Pada kesimpulan di atas, perempuan dapat menjadi pemimpin dalam keluarga jika memenuhi kreterian kepemimpinan sebagaimana disebutkan dalam Q.S. Annisa: 34. Argumentasi ini bersifat sintakmatik dengan melihat makna indikatif ( $m a^{\prime} n a l$ isyaroh) dari kalimat bersyarat dalam ayat itu. Selain itu diperkuat dengan argumentasi paradigmatik dengan melihat konsekuensi fungsi sistem keluarga (mafhum muwafaqoh dan mafhum mukhalafah). Keluarga dipandang sebagai unit sosial dengan fungsi-fungsi yang harus dilakukan oleh mencapai tujuan keluarga. Pelaksana fungsi ini adalah laki-laki dan perempuan yang mengikatkan diri sebagai suami dan istri. Dua pihak ini dapat berbagi tugas, bekerjasama, dan bermusyawarah siapa melakukan apa sesuai dengan kesepakatan mereka.

Sebagai salah satu dari unit sosial, keluarga mengalami perkembangan dari waktu ke waktu secara dialektis menghadapi perubahan sosial lebih luas. Perubahan ini dapat didorong oleh perubahan pola pembagian kerja sosial, perubahan relasi antar kelompok sosial yang menyertainya, perubahan nilai-nilai pribadi dan perubahan relasi gender dalam keluarga. Di bawah ini akan diuraikan bagaimana perubahan-perubahan ini terjadi di dunia terutama sejak munculknya revolusi Inggris dan Perancis Abad ke-18. Pengaruh dua revolusi ini selanjutnya akan dijelaskan dalam contoh kasus di Indonesia, mengenai terbentuknya Undan-Undang Perkawinan, terutama aspek kepemimpinan dalam keluarga. Di akhir penjelasan, akan dipaparkan model kerjasama kepemimpinan antara laki-laki dan perempuan untuk mencapai tujuan keluarga.

1. Revolusi Inggris dan Perancis Abad ke-18 sebagai akselerator perubahan sosial di dunia

Perkembangan masyarakat modern dalam hal pembagian kerja untuk menyelenggarakan kehidupan sehari-hari sudah sangat maju dan dinamis. Dimulai dari sektor ekonomi, pembagian kerja telah berubah ketika industrialisasi mulai dikenalkan di Eropa abad ke-18. Penemuan mesin uap dan pembangunan pabrikpabrik untuk mengolah bahan mentah menjadi bahan setengah jadi dan barang jadi tumbuh sangat pesat. Mesin dan pabrik telah menggantikan hewan dan manusia sebagai tenaga penggerak pekerjaan. Masyarakat yang semula bertumpu pada produk pertanian, beralih dengan cepat ke sektor industri. Struktur masyarakat feudal yang dihidupi oleh sector ekonomi pertanian merosot, dan masyarakat kapitalis dikenalkan dengan semangat persaingan. Setiap individu dihargai kemampuannya untuk memproduksi lebih banyak, dan memberikan keuntungan lebih banyak.

Nilai-nilai dasar kemasyarakatan turut berubah. Kemerdekaan individu mulai dikenalkan, dan progresifitas kerja mulai digiatkan. Nilai-nilai lama dari masyarakat pertanian dengan pola mengandalkan musim tanam, berubah menjadi nilai-nilai harian, mingguan, dan bulanan berdasarkan produksi yang dihasilkan. Komunalisme masyarakat tani berganti menjadi individualisme masyarakat industry. Perubahan sosial ekonomi yang cepat ini mempengaruhi terhadap 
perubahan kontrol atas manusia dalam ruang publik, yaitu dunia politik. Revolusi Perancis terjadi pada abad ke-18 akhir, mengubah tatanan negara absolut menjadi negara demoktratis. Perubahan ini dengan cepat berpengaruh ke seluruh negara Eropa, dan lambat laun mempengaruhi perubahan-perubahan negara di seluruh dunia.

Lalu, apa pengaruh perubahan sosial ekonomi dan sosial politik ini terhadap lembaga keluarga yang saat ini kita bicarakan?

2. Modernisasi Masyarakat Muslim mempengaruhi Perubahan Kelembagaan Keluarga

Paruh akhir Abad komersial abad ke-15 sampai dengan abad ke-17, telah membawa masyarakat Eropa ke seluruh dunia untuk mengeksplorasi kekayaan dengan teknologi transportasi dan persenjataan modern senjata mereka. Penjajahan menyebar di berbagai negeri muslim. Perancis menjajah Mesir dan Aljazair, Inggris menjajah negara-negara Afrika dan India. Spanyol menjajah Amerika Latin dan Indonesia Timur. Inggris, Perancis, Spanyol, menjajah tanah Indian yang disebut Amerika. Belanda menjajah Indonesia, dan sebagainya.

Ketika penjajahan berlangsung, motif kepenguasan ekonomi berubah menjadi kepenguasaan politik. Hal ini seperti tertulis dalam Laporan Tahunan berjudul Hindia Belanda 1930 (Stroomberg, 2018, hal. 45-46). Pengaruh penguasaan ini mengubah tata masyarakat, semula secara hukum (Hoadley, 1994, hal. 1-8). Tata hukum ini ketika dijalankan mengubah struktur pengambilan keputusan di tingkat publik pemerintahan. Hal ini mempengaruhi terhadap perubahan-perubahan praktik sosial dan kelembagaan yang menopangnya, salah satunya adalah keluarga.

Di Indonesia, hukum Islam menyangkut keluarga bertemu dengan hukum positif yang dikenalkan oleh Pemerintah Kolonial Belanda. Belanda pada abad ke-19 memberlakukan kebijakan receptie dengan mengafirmasi hukum adat bagi masyarakat, termasuk hukum Islam bagi kelompok muslim. Hukum material keluarga Islam memiliki sistem pendukung hukum procedural yang disediakan oleh pemerintah kolonial, yaitu Administrasi Penghulu (Hisyam, 2001, hal. 11) dan Raads Agama atau Perangadilan Agama. Praktik pelaksanaan syari'at segera menyebar secara lebih leluasa di komunitas-komunitas muslim karena kebijakan resmi ini. (Hoadley, ...)

\section{Perubahan Kesadaran Relasi Gender dalam Keluarga}

Pada abad ke-19 Pemerintah Kolonial Hindia Belanda di Indonesia memberlakukan politik balas budi atau dikenal dengan politik etis. Kebijakan ini menyatakan bahwa Pemerintah Kolonial bertanggungjawab untuk memajukan kualitas kehidupan Bumi Putra atau penduduk jajahan. Kemunculan politik ini merupakan reaksi atas kebijakan sebelumnya, yaitu tanam paksa, yang diberlakukan sejak tahun 1830 untuk oleh Gubernur Van Den Bosch untuk memulihkan keuangan Pemerintah Belanda karena kebangkrutan beaya Perang Jawa (1825-1830) dan Perang di Eropa. (Stroomberg, hal. 49).

Salah satu dampak dari politik etis ini adalah munculnya gerakan perempuan di Indonesia untuk menyuarakan kepentingan perempuan. Kaum perempuan bangkit memberdayakan diri di hadapan laki-laki. Pada awal abad ke-20, Kartini merintis Sekolah Perempuan di Semarang, dan segera pengaruhnya menyebar ke seluruh kota-kota di Jawa dengan mendirikan Sekolah Perempuan serupa. Walaupun masih lemah, namun kesadaran gender ini sedikit demi sedikit 
berkembang pada masa selanjutnya. Pada tahun 1912 telah dimulai kemunculan organisasi perempuan. Satu decade berikutnya, pada tahun 1928 Kongres Perempuan Pertama diselenggarakan, dan dihadiri oleh wakil dari 30 organisasi perempuan di Indonesia (Blackburn, 2007, xxii-xxiii).

Rekomenasi kongres perempuan ini pertama ini memiliki pengaruh besar terhadap perubahan kesadaran gender dan relasi gender. Salah satu rekomendari itu adalah pendirian Perikatan Perempuan Indonesia (PPI), dengan tujuan memajukan perempuan dan merespon perkara-perkara perempuan. Strategi pendidikan dengan pendiria Sekolah perempuan dikuatkan, pendirian media perempuan dibuat, dan advokasi aturan hukum keluarga dilakukan berdasarkan prinsip kesetaraan. Salah satu respon kuat adalah terhadap adanya perjanjian nikah atau ta;liq talak dengan menuntut pemerintah supaya memperkuat statusnya dalam hukum perkawinan Islam (Blackburn, hal 22-31).

Pada tahun 1935 diadakan Kongres PPI II di Jakarta, dan salah satu rekomendasinya adalah melanjutkan upaya untuk memperkuat tuntutan pencantuman ta'liq talaq sebagai senjata perempuan dalam keluarga. Kongres itu mempelajari kedudukan perempuan dalam Islam dan mengusulkan adanya rencangan Ordonansi Perkawinan, sampai terbitnya Rancangan dari Pemerintah Hindia Belanda pada tahun 1937, walau kemudian ditolak oleh masyarakat. Setelah Indonesia Merdeka, Kongres perempuan terus berjuang mengadvokasi peraturan perkawinan, berdialog dengan Dewan Perwakilan Rakyat, sampai munculnya rancanan RUU Perkawinan tahun 1973. Pada tahun 1974 RUU itu ditetapkan oleh MPR sebagai UU Perkawinan, dengan UU No. 1 tahun 1974 tentang Perkawinan. Pada UUP 1974 ini kedudukan laki-laki dan perempuan diakui setara di hadapan Hukum, dan hak-hak perempuan mendapatkan kepastian untuk dilindungi. (Subadio, 1981, hal. 7-29).

\section{Perempuan Pemimpin Keluarga}

Dinamika sejarah perjuangan perempuan sampai mendapatkan kepastian hukum mengenai relasi laki-laki dan perempuan yang setara dalam Undang-Undang Perkawinan menunjukkan bahwa perubahan relasi gender terjadi. Relasi gender ini tidak saja berupa wacana intelektual, namun sampai pada perubahan kelembagaan hukum yang dipraktikkan di masyarakat sampai sekarang.

Namun, meskipun ada jaminan kedudukan yang setara di hadapan hukum bagi perempuan dan laki-laki, aturan-aturan lain masih bersifat tradisional seperti dalam fiqh klasik. Laki-laki menjadi pemimpin keluarga, dan perempuan menjadi ibu rumah tangga. Poligami masih diakui meskipun dengan batasan yang ketat. Apakah dinamika perubahan ini akan sampai pada pengakuan bahwa perempuan dapat menjadi pemimpin keluarga?

Ada dua fenomena terkait hal ini di Indonesia. Pertama bahwa perempuan kepala keluarga itu ada, dan secara hukum diakui. Hanya saja, keluarga yang dimaksud adalah ketika suami telah meninggal dunia, atau telah cerai dari istrinya. Istri ketika mengurus keluarga yang ditinggalkan suaminya beralih menjadi kepala keluarga. Para perempuan kepala keluarga melakukan penguatan terhadap anggota dan melakukan advokasi hak-hak mereka kepada pemerintah. Mereka mendirikan perkumpulan yang disebut PEKKA, Perempuan Kepala Keluarga (https://pekka.or.id/).

Kedua, secara sosiologi, praktik perempuan pencari nafkah utama keluarga yang masih memiliki suami banyak terjadi di Indonesia. Hal ini terutama dialami 
oleh para pekerma migran di luar negeri. Banyak perempuan dari masyarakat miskin pergi merantau dan bekerja di luar negeri. Mereka mengirimkan uang untuk keluarga, dan suami mengelola uang itu untuk keluarga.

Dua fakta di atas telah menunjukkan secara relatif bahwa eksistenai perempuan sebagai kepala keluarga adalah nyata. Hanya saja, fakta pertama menyimpan pertanyaan bagaimana jika perempuan kepala keluarga ini menikah lagi, apakah dia masih tetap menjadi kepala keluarga. Fakta kedua merupakan tuntutan sosiologis yang nyata di sebagian masyarakat. Namun demikian fakta ini belum mendapatkan afirmasi hukum, karena secara formal legal kepala keluarga tetap ada di tangan suami, sedangkan istri menjadi kepala keluarga secara informal non legal.

\section{Kerjasama Suami Istri dalam Memimpin Keluarga}

Laki-laki sangat diuntungkan dalam alam masyarakat patriarki, sampai dengan alam modern sekarang. Kukuhnya rasionalitas ilmiah sebagai penyangga masyarakat modern merupakan dukungan bagi budaya patriarki. Akal pikiran, dan bukan perasaan, yang memimpin peradaban modern. Moda ekonomi kapitalis yang berorientasi pada akumulasi laba bertemu dengan rasionalitas dengan menggunakan sains sebagai instrument bagi pengembangan operasionalnya. Dalam hal ini tidak ada ruang bagi kepekaan perasaan, keseimbangan antara perasaan dan akal pikiran yang masuk dalam manajemen emosi, bagi masyarakat modern.

Meskipun telah banyak usulan di bidang organisasi dan tata usaha ekonomi untuk lebih mempertimbangkan perspektif perempuan, hal ini belum berarti posisi perempuan mudah. Laki-laki tetap memiliki kedudukan yang tinggi dalam berbagai lembaga sosial, baik secara nilai maupun praktik. Hal ini menempatkan laki-laki memiliki modalitas yang kuat untuk menentukan relasi gender dan kerjasama dalam masyarakat, terutama dalam keluarga.

Modalitas laki-laki dapat meliputi tiga ranah struktur kemasyarakatan dalam pengertian Giddens, meliputi struktur hegemoni, signifikasi dan legitimasi. Modalitas dalam struktur hegemoni berupa pemegang kontrol atas orang (politik) dan barang/jasa (ekonomi). Laki-laki sebagai suami memiliki kedudukan kepala keluarga, dan dengan mengabaikan kondisi faktualnya, laki-laki memiliki kuasa secara legal dan sosial untuk menentukan keputusan keluarga menyangkut ekonomi dan politik. Interaksi dalam hal ini terjadi ketika keluarga memerlukan bertransaksi tertentu dengan bank yang mewajibkan suami sebagai pemegang kuasa, menyekolahkan anak, menikahkan anak, dan lain-lain.

Tindakan laki-laki untuk musyawarah dalam memutuskan segala sesuatu dengan istri merupakan langkah strategis untuk membangun role model keadilan gender dalam keluarga. Keputusan-keputusan terpenting yang menentukan masa depan keluarga dan anak merupakan keputusan bersama. Hal ini akan meningkatkan rasa keadilan gender, menurut istilah Sarah H. Longwee, tidak saja pada aspek kesejahteraan, namun juga pada aspek askes, partisipasi dan kontrol urusan keluarga.

Pada struktur signifikasi, laki-laki akan mudah melakukan pengaruh wacana bagi masyarakat, baik dengan audience perempuan maupun laki-laki. Laki-laki dapat memanfaatkan keuntungan ini dengan aktif menyuarakan pentingnya membangun keluarga yang sakinah, mawaddah wa rahmah, dengan 
mengembangkan kerjasama yang setara antara suami dan istri. Keuntungannya, suami akan merasa lebih ringan menanggung beban keluarga di satu sisi. Di sisi lain, istri akan merasa dimanusiakan, dan dengan demikian kualitas psikhis akan maksimal dengan merasa setara dan leluasa.

Laki-laki juga memiliki modalitas kuat dalam struktur legitimasi. Secara hukum, laki-laki masih diakui secara formal sebagai kepala keluarga. Hal ini berpengaruh secara sosial, bahwa suami selalu menentukan persoalan publik bersama dengan laki-laki lainnya dalam masyarakat. Keabsahan ini dapat dimanfaatkan untuk memberikan contoh praktik adil gender di hadapan masyarakat umum terkait interaksi dengan istri dan anak-anak. Contoh praktik moral keadilan gender merupakan legitimasi paling kuat dibandingkan dengan wacana dalam seminar dan kelas-kelas yang lebih kecil.

\section{CONCLUSION}

Paparan dapat memberi beberapa pelajaran antara lain pertama, bahwa perubahan sosial mempengaruhi terhadap perubahan keluarga, termasuk kepemimpinan lakilaki dan relasi gender. Kedua, secara tekstual keagamaan, makna kepemimpinan dapat diperluas tidak saja oleh laki-laki, namun juga oleh perempuan. Kepemimpinan dapat dimaknai sebagai kewenangan mengambil keputusan, dan kewenangan melaksanakan hasil keputusan musyawarah keluarga. Ketiga, laki-laki dalam konteks masyarakat patriarki memiliki modalitas kuat untuk berkerjasama dengan perempuan dalam memimpin keluarga, baik dari aspek dominasi, signifikasi maupun legitimasi.

\section{REFERENCES}

Ash-Showi, 'Allamah Asy-Syaikh Ahmad. Hasyiah Al-'Allamah Ash'Showi 'ala Tafsir Al'Jalalaini. Indonesia: Dar Ihya Al-Kutub Al-'Arobiyah.

Al-Qurthuby, Abi Abdillah Muhammad bin Ahmad Al-Asnhory. Al-Jami' li Ahkam Al-Qurani. Juz 5.

Blackburn, Susan. 2007. Kongres Perempuan Pertama, Tinjauan Ulang. Jakarta: Buku Obor \& KITLV-Jakarta.

Harun, Salman, Prof. Dr. H. 2017. Kaidah-Kaidah Tafsir, Bekal Mendasar untuk Memahami Makna Al-Quran dan Mengurangi Kesalahan Peahaman. Jakarta: P.T. Qof Media Kreativa.

Hisyam, Muhammad. 2001. Caught Between Three Fires, The Javanese Pengulu under The Dutch Colonial Administration 1882-1942. Jakarta: INIS

Hoadley, Mason C. 1994. Selective Judicial Competence, The Cirebon - Priangan Legal Administation, 1680-1792. Ithaca: SEAP

Khollaf, Abdul Wahab. 1978. Úlum Ushul Al-Fiqh. Kuwait: Dar Al-Qolam.

Khairuddin, Drs. H. H.SS. 1997. Sosiologi Keluarga. Yogyakarta: Liberty.

Muhammad, K.H. Hussein, dkk. 2006. Modul Kursus Islam dan Gender, Dauroh Fiqh Perempuan. Cirebon: Fahmina Institute.

Qothon, Manak. Mabahits fi 'Ulum Al-Qurani. Mantsurot Annahr Alhadits.

Stroomberg, Dr. J. 2018. Hindia Belanda 1930. Yogyakarta: IRCISoD

Subadio, Maria Ulfah, SH. 1981. Perjuangan Untuk Mencapai Undang-Undang Perkawinan. Jakarta: Yayasan Idayu. 